\title{
Fundamental Social Rights and Existenzminimum ${ }^{*}$
}

\author{
Cláudia Toledo \\ Universidade Federal de Juiz de Fora
}

\begin{abstract}
While fundamental individual rights are unquestionably taken as subjective rights, the same does not happen with fundamental social rights. If they are subjective rights, they are justiciable. The main argument in favor of this understanding is based on liberty. The main argument against is the so called formal argument. In relation to the pro argument, liberty can be either juridical or factual. Juridical liberty has no value without factual liberty, because the right to liberty is only put into practice if one has the factual preconditions for its exercise. The argument against is that their justiciability displaces the competence of the elaboration of public politics from Legislative and Executive to Judiciary Power, what violates the principles of separation of powers and democracy. Nevertheless they are subjective rights indeed, but special ones: they are prima facie subjective rights. There is only one subjective right that is a priori considered definitive: the right to Existenzminimum. ${ }^{1}$ Its content is not settled, but it is quite unequivocal that the rights to simple housing, fundamental education and minimum level of medical assistance are part of it. Existenzminimum is then related to the minimum necessary for factual liberty. Against the justiciability of fundamental social rights, there are also arguments related to juridification of politics, administrative discretion and the possible reserve clause. The counter-arguments refer to original and exceptional competence, necessary objective proof of state's economical incapability, prohibition of State's will, principles of legality and of non-obviation of Judiciary jurisdiction, Existenzminimun guarantee.
\end{abstract}

Keywords: subjective rights, justiciability, dignity, liberty, formal principles, competence

\section{Fundamental Social Rights and Human Dignity}

Fundamental rights are the positivation of human rights (which have a moral character) in the national Law. Such juridicization is the result of secular political struggles. According to Robert Alexy, ${ }^{2}$ the moral constructions and claims from which the positivation of human rights result go back to the Classical Antiquity with, for example, Seneca texts, stoic who preached the cosmopolitism-everyone is the manifestation of a universal spirit. In turn, the ideas of dignity and equality were developed by Christian theology (Genesis, New Testament, and especially Paul), until the 18th century Enlightenment, when finally it has got to its peak with the Declaration of the Rights of Man and Citizen.

While fundamental individual and political rights were consensually understood as subjective rights since the first moment of their positivation, the same did not happen with fundamental social rights, which appeared after those ones, only in 19th century. Until today, it is still polemical if fundamental social rights may be identified as real subjective rights or mere objective norms. As subjective rights, they are judicially demandable,

*This article presents the results of the post-doctorate research developed from September 2011 until December 2012 with Prof. Robert Alexy in the Juristisches Seminar of Christian-Albrechts Universität zu Kiel, Germany.

Cláudia Toledo, Ph.D., Post-Doctorate, Philosophy of Law, Universidade Federal de Juiz de Fora, Brazil; main research fields: Philosophy of Law, Theory of Law, Fundamental Rights, and Legal Argumentation. Email: toledo.claudia@uol.com.br. 
that means they are justiciable. ${ }^{3}$ As objective norms, they are in an orientation directed to Legislative and Executive Powers for the elaboration and implementation of State's goals or its political programs.

According to Alexy, fundamental social rights are "rights of the individual before the State, to something that the individual, if had enough means and if there were sufficient offer in market, could also have from particulars" (Alexy 1994, 454): right to health, education, work, and housing—all of them substantially guided by the idea of human dignity. ${ }^{4}$

Dignity is a semantically open concept, i.e., a concept whose definition does not present a high accuracy level, but only joins a non-exhaustive group of related characteristics. Alexy states that the concept of dignity goes beyond the generic formula according to which the human being can not be transformed into an object (Alexy 1994, 322). There are a lot of subjective rights related to it: life, liberty, equality, physical integrity, privacy rights, and many others. ${ }^{5}$ Because of this, Alexy synthesizes the wealth of adjectives and nouns related to the concept of dignity which, although exuberant, do not formulate a definition, due to the randomness of their choice, saying that dignity can be expressed by a joint of concrete conditions, which must be present for its assurance. It is certain that the content of this joint is not unanimous, but it is not completely different either. There is convergence of many aspects, so that for many times the differences are related only to the weight given to some conditions of the same joint.

\section{Fundamental Social Rights: Prima Facie Subjective Rights and Human Dignity}

There are arguments in favor of and against the consideration of fundamental social rights as subjective rights. The main pro argument is based on liberty. The main argument against this understanding is the so called formal argument, even though there is also the substantial one (Alexy 1994, 458-465).

Liberty can be either juridical (right to do or not something) or factual (the concrete possibility of choosing among the allowed alternatives). According to this argument, juridical liberty does not have any value without factual liberty. The German Constitutional Court (Bundesverfassungsgericht) states that "the right of liberty would have no value without the factual preconditions for its exercise". 6 Material and intellectual goods are then preconditions for selfdetermination. Though, factual liberty is not a matter of everything-or-nothing, but a matter of degree.

The formal argument against the definition of fundamental social rights as subjective rights is that they dislocate the competence of the establishment of social policies from Legislative Power to the Judiciary one. This causes a judicial determination of the budget plans, which is incompatible with Constitution.

The substantial argument against this understanding refers to the material principles: juridical liberty of the third party, ${ }^{7}$ the other social rights ${ }^{8}$ and the collective interests. ${ }^{9}$

Nevertheless, according to Alexy, fundamental social rights are subjective rights indeed and this is today pacific understanding of the Bundesverfassungsgericht. The author develops his thought based on his theory of principles, considering fundamental social rights as prima facie subjective rights. Thus, their norms have a surplus content or an ideal one.

\section{Fundamental Social Rights: Positive Rights under Principle Structure}

Fundamental rights are presented under the principle structure. ${ }^{10}$ Their mandatory characteristic is stipulated by the biding clause in Constitution (art. 1, paragraph 3), which denies their programmatic character, stating that they are immediately in force. ${ }^{11}$ 
According to a detailed and rigorous conceptual specification, Alexy (1994) classifies fundamental social rights as rights to something, as positive rights. Their positive action can be either factual or normative. On one hand, they are absolute rights, because they oblige the generality of the society members. On the other hand, they are general, because they do not need acquisitive deed. They are universal from the holder's point of view, because they are rights before everybody. From the logical point of view, they are abstract rights, i.e., rights that are determined only in the concrete situation.

Fundamental social rights have a wide range, once they are frequently identified through the interpretation of juridical norms conjunctions, in which they are explicitly or implicitly presented. The understanding that there is a fundamental right only if there is a correspondent normative provision about it is an extreme positivist vision of Law, that promotes the literal or genetic interpretation rather than the systematic one, which is broader and more complex. In German theory and case law, the integral and wide comprehension of constitutional text is dominant. ${ }^{12}$ This is the kind of interpretation required by the high semantic openness that not only fundamental social rights, but all fundamental rights have, due to their high value density (they rule the values socially taken as essential).

Many times, the recognition of fundamental social rights happens through a counterfactual argumentation: if the non-recognition of a juridical position leads to an irreconcilable consequence with the constitutional order, such juridical position must be recognized. Thereby, the criterion for the correction of the justification of a fundamental social right adscription to another positive right is the demonstration that the denial of this adscription is wrong, because it contradicts the juridical system as a whole (Arango 2000, 45-46). This is possible through a correct constitutional foundation.

Alexy's theory of legal argumentation focuses on precisely the correction in the justification of the value judgments that integrate juridical norms and the juridical discourse. So it delineates forms and rules to be complied, which act as objective criteria, procedures to achieve the maximum rationalization of juridical discourse. $^{13}$

\section{Existenzminimum as Definitive Subjective Right}

There is a core of rights, which appear a priori as definitive. It stems from the totality of fundamental social rights. The set of these rights form exactly the Existenzminimum. ${ }^{14}$ As a joint of definitive rights, the Existenzminimum is justiciable, i.e., its immediate compliance is demanded from public power.

If its content is not pacific even in Germany yet, which was one of the first countries to create this concept, it is for sure controversial in Brazil. ${ }^{15}$ Alexy understands that it is compounded by the right to simple housing, fundamental education and a minimum level of medical assistance (Alexy 1994, 466). It is certain that the content of the Existenzminimum varies according to the cultural, local, economical, and historical context-the richer the country is, the broader the Existenzminimum is. ${ }^{16}$

It is a concept oriented by the idea of factual equality. Juridical liberty is empirically enabled based on it. Nevertheless, it is difficult to define precisely in relation to which aspects this factual equality must exist. The recourse to historical comparisons and also comparisons with the reality of other countries is necessary. Its content is always related to the present conditions, guided by the effectively existing life level, once the equality principle appears as means to assure human dignity.

Indeed, everything turns to be a matter of pondering, indispensable in cases that involve fundamental rights. $^{17}$ 
The assertion of the Existenzminimum and its consideration as a definitive subjective right are established nowadays in German case law. The Constitutional Court relates it to the principles of human dignity, free development of personality, equality, Social State and right to life and to physical integrity. Although sparse references to the Existenzminimum had already been done in the 1990's, its precise determination was done by the decision BVerfGE $(125,175$, on February 9th, 2010).

In Brazil, the first reference to it was done by the Constitutional Court (Supremo Tribunal Federal) in 2004 (ADPF 45/DF, 2004). ${ }^{18}$ From then on, the use of Existenzminimum notion in Brazilian constitutional case law is increasingly present. Only between 2004 and 2008, there was a growth of more than $300 \%$ in relation to its assertion and protection. ${ }^{19}$

This first decision related to Existenzminimum stated the necessity of its preservation "in favor of individual's integrity and intangibility." The new Brazilian constitutional hermeneutics began to assure immediate effectiveness to all fundamental rights. They are considered "full effectiveness norms".

Brazilian Constitutional Court considers that there must be protection against "situations that threaten the Existenzminimum," because without it, human dignity is "mere utopia" (AI 583594/SC, 2009).

The insurance of "human dignity conditions", which is presented as a "central constitutional goal" (AI 583594/SC, 2009), means not only to assure the protection of fundamental individual rights, but also the "minimum material conditions of existence" (ADPF 45/DF, 2004). Thus, Existenzminimum appears as the "joint of fundamental rights without which human dignity is confiscated" (AI 684829/SP, 2008).

State's omission in complying with fundamental social rights which are part of the Existenzminimum constitutes an "illicit conduct," whose consequence is the judicial establishment of deadlines for the State's provision through "imposition of daily fines." 20

\section{Fundamental Social Rights: Justiciability and Existenzminimum}

\subsection{Arguments Against}

Here comes the polemic questioning about the judicial decisions which order state's compliance with fundamental rights—especially the social ones. The argument is that these decisions would be improper due to these main reasons:

(1) This situation would configure a politics' juridicization, since Judiciary Power would be determining the acts of the other powers, what would assail the principle of separation of powers;

(2) The principle of democracy would be affected too, because the political decisions' legitimacy belongs to Legislative and Executive Powers, compounded by popular representatives;

(3) Public power has administrative discretion, which would be taken away by Judiciary Power acts;

(4) The recourse to the possible reserve clause is suitable, when the effectiveness of fundamental social rights is financially unviable for the State, due to their high costs.

\subsection{German Constitutional Court Case Law and Alexy's Thought}

Both German and Brazilian Constitutional Courts consider and answer these arguments in the same way. Once the concept and the demand of Existenzminimum are older in Germany, the position of German Judiciary Power is more consolidated in this respect.

These are some German Constitutional Court positions: 
(1) Indeed, Legislative Power has the original competence to decide about the limits of social assistance, how it can and must be done, according to the existing means of the State and its other equally important obligations;

(2) Nevertheless, when the question is about the assurance of the minimal conditions for a dignified existence, Judiciary Power is competent, because this is duty of the "public community" of which it takes part.

Alexy (1994) analyzes the arguments in favor and against the justiciability of fundamental social rights and its implications. He states that:

(1) Fundamental social rights are so important that their assurance cannot be left to the decision of a simple parliamentary majority;

(2) There is no previous determination of which fundamental social rights are definitive;

(3) This determination is a matter of pondering among principles-on one hand, there is the principle of factual liberty, on the other hand, the formal principles of democracy and separation of powers, besides the material principles of third party's juridical liberty, of other's fundamental social rights and of collective interests.

\subsection{Brazilian Constitutional Court Case Law}

Brazilian Constitutional Court (1988) has stated that:

(1) Fundamental social rights are justiciable. Since the decision of 2004, Judiciary Power is asserted as competent to decide claims related to the non-compliance with fundamental social rights;

(2) These rights are not only a matter of social politics derived from programmatic and non-imperative norms, subordinated to Executive Power. They have immediate effectiveness;

(3) They are subjective rights really, not mere objective norms, which oblige the State only objectively, that means, they justify duties, but do not grant rights;

(4) They represent an inalienable constitutional prerogative, which is not subordinated, during its concretization process, to reasons of pure governmental pragmatism;

(5) Even though the prerogative to formulate and execute public policies is primarily of Legislative and Executive Powers, if the public bodies primarily competent do not comply with the political-juridical charges mandatorily imposed to them, coming to compromise, with their omission, the effectiveness of fundamental social rights, Judiciary Power is exceptionally competent to determine the implementation of public policies especially if they are defined by Constitution itself; ${ }^{21}$

(6) The simple allegation of the State financial incapacity followed by the recourse to the possible reserve clause is not enough for the non-compliance with fundamental social rights. The referred material limitation must be objectively demonstrated. Otherwise, the public power behavior is illicit. After all, taking the rights seriously means taking the shortage seriously. State shortage must be articulated with the "allocation choices" of public spending. However, reasonability of the demanded pretension is necessary;

(7) Judiciary Power is competent to determine the compliance with fundamental social rights:

(7.1) In case of State's abusive behavior, such as State's inertia, unreasonable procedure or procedure with clear intention to neutralize the effectiveness of fundamental social rights;

(7.2) In case of State's arbitrariness towards the compliance with fundamental social rights, extrapolating the legal discretion power; 
(7.3) On the basis of the fact that the conformation liberty of Legislative and Executive Powers is not absolute, but has a relative character;

(8) There is the necessity of harmony of the public administration acts with the principles of legality and of non-obviation of judicial control. Public power is subordinated to a legally biding constitutional mandate, which represents a factor of political-administrative discretion limitation;

(9) Judiciary Power interference in public administration does not necessarily imply offense to the principle of separation of powers, because the Legal State is subjected to jurisdiction. Due to the high biding degree of public power to the satisfaction of fundamental social rights by virtue of its essential character, it is possible that Judiciary Power, if State is in default, determine it to implement public policies constitutionally provided. After all, public spending with public policies is subordinated to the administrator's convenience judgment and opportunity, but not to his arbitrariness;

(10) The conception of Existenzminimum prevails over the possible reserve clause one (ADPF 45/DF, 2004; AI 658491/GO, 2011; RE 667745/SC, 2012);

(11) The necessity of satisfaction of the minimal conditions for a dignified existence, i.e., of the Existenzminimum is untouchable. Thus, the establishment of priority aims is due. The discussion about which other project might receive investment must be related only to the remaining resources.

In virtue of all these positions, Brazilian Constitutional Court considers that there is really a political dimension (ADPF 45/DF, 2004) in constitutional jurisdiction, which ultimately controls the subordination of all State acts to the Constitution. Constitution is precisely the materialization of the encounter between Politics and Law. The observing and compliance with fundamental rights are exactly the result of the public power subordination to constitutional norms. ${ }^{22}$

\section{Fundamental Social Rights: Clear Inferences}

In short, two conclusions are clear in relation to fundamental social rights:

(1) All subjective rights are justiciable. They are prima facie rights that become definitive in the concrete case. Alexy emphasizes this understanding by stating that "non-justiciable fundamental rights are a lie." ${ }^{, 23} \mathrm{He}$ adds that the justification specifically of fundamental social rights is to promote to those who were not lucky to be born in a family with reasonable economic situation, the access to similar opportunities and material goods;

(2) The effectiveness of fundamental social rights depends on the way the individual is seen by the society to which he belongs: if as a legal subject or as a juridical order object (Arango 2000, 29-30; 50-55). Increasingly, the countries, in the search of democracy - which always develops as a process and therefore it is built by forward and backward, consider the individual as a holder of subjective rights and progressively no longer as an object of public interest to be treated by State's social assistance service, in such a way that public security and social order are ensured. In other words, individuals are always seen as disturbing objects. Individuals are not endowed with a value on their own, but a social problem to be solved. Briefly, to respect individual's fundamental rights means to take the individual seriously.

\section{Notes}

\footnotetext{
1. "Existential minimum."
} 
2.Vorlesung "Staatsrecht II," Christian-Albrechts Universität zu Kiel, April 5th, 2012.

3. Language is recognized as a cultural manifestation of the society, reflecting its ethos. This ethos is in constant formation and modification. So, the language is necessarily flexible, adaptable, and passive of enrichment according to the growth of the complexity of its intersubjective relations. The creation and posterior demanding of concretization of fundamental social rights are examples of this social transformation. The development of language vocabulary makes the social transformation clear. The arising of the terms "justiciability," "justiciable," and "juridicization" is an illustration of this process.

4. See also ALEXY, Robert. Grundrechte. Enzyklopädie Philosophie-hg. V.H.J.Sandkühler. Hamburg: Feliz Meiner Verlag, Bd. 1, 1999. ALEXY, Robert. A theory of constitutional rights postscript. Oxford: Oxford University Press, 2010.

5. These rights are mostly fundamental individual rights. This makes clear the close relation among all fundamental rights, what demands the vision of their indivisibility.

6. BVerfGE 33,303.

7. Fundamental social rights would collide with liberty rights, because they are highly expensive, so the State can only accomplish them with a huge taxation on those who are not demanding them, that is, the property owners.

8. Everyone demanding the equal exercise (in the same degree) of fundamental social rights turns unfeasible the rights themselves, because the State cannot bear the costs of the requirement of the exercise of fundamental social rights by everybody in the same measures, as high as possible, that is, with the highest patterns of education, health, housing, and work.

9. There would be a preponderance of the individual's subjective rights-especially if many individuals demand the exercise of fundamental social rights- to the detriment of the whole society's interests, of the collective good.

10. See BOROWISK, Martin. Grundrechte als Prinzipien. 2nd ed. Baden-Baden: Nomos, 2007. ALEXY, Robert. Recht, Vernunft, Diskurs: Studien zur Rechtsphilosophie. Frankfurt am Main: Suhrkamp, 1995.

11. "The following rights [fundamental rights] bind Legislative, Executive and Judiciary Powers as immediately applicable right" (Alexy 1995, 264-267).

12. The classic-liberal interpretation of fundamental rights identifies them only with liberty, i.e., negative rights, from which results a marked limitation of their content.

13. See ALEXY, Robert. Theorie der juristischen Argumentation. 7th ed. Frankfurt am Main: Suhrkamp, 2012. ALEXY, Robert. Teoría del discurso y derechos constitutionales. México: Distribuciones Fontamara, 2005.

14. A fundamental social right only becomes a definitive right when the factual liberty principle has a heavier weight than the colliding principles. The understanding in Germany and in Brazil is that, among all fundamental social rights, only the Existenzminimum is immediately justiciable, because it is not prima facie right, but a definitive one.

15. See TORRES, Ricardo Lobo. Direito ao mínimo existencial. Rio de Janeiro: Renovar, 2012.

16. For example, "fundamental education" considered by Alexy as one of the rights that compound the Existenzminimum includes high school and technical education, what clearly does not correspond to Brazilian reality.

17. See ALEXY, Robert. Derechos sociales y ponderación. Madri: Fundación Coloquio Jurídico Europeo, 2007. ARANGO, Rodolfo. Basic Social Rights, Constitutional Justice and Democracy. Ratio Juris, Vol. 16, 2003.

18. Minister Celso de Mello was the rapporteur.

19. Until last year, there were more than 80 decisions directly referred to Existenzminimum.

20. According to art. 644 and 645/CPC, Brazilian Code of Civil Procedure.

21. The identification of omissions or State actions that violate fundamental social rights corresponds to the determination of what is legally due and what is only legally acceptable. The border between both hypothesis is markedly fluid, depending on the conditions and circumstances of the concrete case, as all the situations that involve fundamental rights.

22. Nowadays in Germany, the Existenzminimum concept transcends the juridical sphere and it is an idea that guides the Executive Power measure called Hartz IV, a program created in 2005, whose aim is the support to the unemployed. However, its sense goes beyond, once it seeks the stipulation of the due values to each specific concrete case, in order to ensure the minimal material conditions necessary to the assurance of human dignity. That is, the pecuniary amount corresponds to the Existenzminimum. The amount of $382 €$ is monthly due to the individual, added to the financial cover for proper housing and health care. In Brazil, there is a similar government program called "Bolsa-Família" since 2004. It is also guided by the idea of human dignity and ensures the minimum benefit of R $\$ 70,00$ (about US\$29,80) to the individual.

23. Vorlesung "Staatsrecht II," Christian-Albrechts Universität zu Kiel, April 5th, 2012.

\section{Works Cited}

Alexy, Robert. Theorie der Grundrechte [Theory of Fundamental Rights]. Baden-Baden: Suhrkamp, 1994.

---. .Recht, Vernunft, Diskurs: Studien zur Rechtsphilosophie [Law, Reason, Discourse: Studies of Philosophy of Law]. Frankfurt am Main: Suhrkamp, 1995.

---. “Grundrechte.” [Fundamental Rights]. Enzyklopädie Philosophie [Philosophy Encyclopedia].-hg. V.H.J. Sandkühler.Hamburg: Felix MeinerVerlag, Bd. 1, 1999.

---. Teoríadel discurso y derechosconstitucionales [Discourse Theory and Constitutional Rights]. México: Distribuciones Fontamara, 2005 
---. Derechossociales y ponderación [Social Rights and Pondering]. Madri: Fundación Coloquio Jurídico Europeo, 2007.

---. A theory of constitutional rights postscript. Oxford: Oxford University Press, 2010.

---. Theorie der juristichen Argumentation [Theory of Legal Argumentation]. Frankfurt am Main: Suhrkamp, 7. Auflage, 2012.

Arango, Rodolfo. Der Begriff der sozialen Grundrechte [The Concept of Social Rights]. Baden-Baden: Nomos Verlagsgesellschaft, 2000.

---. Basic Social Rights, Constitutional Justice and Democracy.Ratio Juris, Vol. 16, 2003.

Borowisk, Martin. Grundrechteals Prinzipien [Fundamental Rights as Principles]. Baden-Baden: Nomos, 2. Auflage, 2007.

Torres, Ricardo Lobo. Direito ao mínimo existencial [Right to Existenzminimum]. Rio de Janeiro: Renovar, 2012.

Brazilian Federal Constitution, 1988.

Brazil. Supremo Tribunal Federal [Federal Constitutional Court]. ADPF 45/DF, May 04th, 2004.

Brazil. Supremo Tribunal Federal [Federal Constitutional Court]. AI 583594/SC, December 03rd, 2009.

Brazil. Supremo Tribunal Federal [Federal Constitutional Court]. AI 684829/SP, October 14th, 2008.

Brazil. Supremo Tribunal Federal [Federal Constitutional Court]. AI 658491/GO, September 02nd, 2011.

Brazil. Supremo Tribunal Federal [Federal Constitutional Court].RE 667745/SC, March 05th, 2012.

Germany. Bundesverfassungsgericht [Federal Constitutional Court]. BVerfGE 33, 303, July 07th, 1972.

Germany. Bundesverfassungsgericht [Federal Constitutional Court]. BVerfGE 125, 175, February 09th, 2010. 